\title{
Guidance of Postural Motoneurons Requires MAPK/ERK Signaling Downstream of Fibroblast Growth Factor Receptor 1
}

\author{
Prabakaran Soundararajan, ${ }^{1}$ James P. Fawcett, ${ }^{2,3}$ and Victor F. Rafuse ${ }^{1}$ \\ Departments of ${ }^{1}$ Anatomy and Neurobiology, ${ }^{2}$ Pharmacology, and ${ }^{3}$ Surgery, Dalhousie University, Halifax, Nova Scotia, Canada, B3H 1X5
}

Identification of intracellular signaling pathways necessary for appropriate axon guidance is challenging because many CNS populations used to study these events contain multiple cell types. Here, we resolve this issue by using mouse embryonic stem (ES) cells that were directed to differentiate into a population of motoneurons that exclusively innervate epaxial muscles [medial median motor column (MMCm) motoneurons]. These ES cell-derived MMCm motoneurons, like their endogenous counterparts, express fibroblast growth factor receptor 1 (FGFR1) and selectively extend axons toward the epaxial trophin FGF8. Unlike wild-type MMCm motoneurons, FGFR $1^{-1-}$ MMCm motoneurons show guidance defects when transplanted into the neural tube of chick embryos. Furthermore, activation of FGFR1 selectively signals through mitogen-activated protein kinase/extracellular signal-regulated kinase (MAPK/ERK) for appropriate guidance in vitro, whereas overexpression of constitutively active MAPK/ERK in transplanted, or endogenous chick, MMCm cells causes guidance defects in vivo. These results indicate that MAPK/ERK activation downstream of FGFR1 is necessary for MMCm motor axon guidance and that ES cell-derived neurons provide an important tool for dissecting intracellular pathways required for axon guidance.

\section{Introduction}

Motoneuron development studies have been instrumental in defining mechanisms by which discrete groups of neurons within the CNS establish connections with their appropriate postsynaptic targets (Landmesser, 2001). A major appeal of this system is its relatively simplistic anatomy and well defined topographic projection patterns (Landmesser, 1978). Early in development, distinct motoneuron subtypes, each expressing unique combinatorial patterns of LIM homeodomain transcription factors, segregate into three discrete columns within the spinal cord (Tsuchida et al., 1994; Shirasaki and Pfaff, 2002). Medial median motor column (MMCm) motoneurons innervate epaxial muscles (primarily postural) lining the vertebrae, whereas limb-innervating motoneurons are located in two lateral motor columns (LMCs). Dorsally derived (primarily extensor) muscles are innervated by motoneurons in the lateral LMC (LMCl), whereas ventrally derived (primarily flexor) muscles are innervated by motoneurons in the medial LMC (LMCm). Studies in

\footnotetext{
Received Oct. 2, 2009; revised Feb. 15, 2010; accepted March 28, 2010.

This work was supported by the Natural Sciences and Engineering Research Council of Canada (V.F.R.) and Canadian Institute of Health Research (J.P.F.). P.S. was supported by a Reynolds Postdoctoral Fellowship from the Department of Pharmacology, Dalhousie University and a studentship from Nova Scotia Health Research Foundation. J.P.F. is a Tier 2 Canada Research Chair in Brain Repair C. Is 1 1/2, Lim1/2, and Lhx3 antibodies were obtained from the Developmental Studies Hybridoma Bank under the auspices of the National Institute of Child Health and Human Development and maintained by the University of lowa, Department of Biology. We thank Drs. Janet Rossant for providing FGFR $1^{\Delta t m k-/-}$ and FGFR ${ }^{\Delta t m k+/-}$ ES cells, Natalie Ahn for providing MEKCA::HA DNA, and Catherine Krull for the providing the pCAX::GFP DNA. We thank Drs. Freda Miller and David Kaplan for providing the AdMEKCA::GFP virus and for their helpful discussions in experimental design. We also thank Drs. Christine King and Craig McCormick for providing the AdGFP virus and assistance in expansion of adenoviruses.

Correspondence should be addressed to either of the following: Dr. Victor F. Rafuse, Department of Anatomy and Neurobiology, Sir Charles Tupper Medical Building, Dalhousie University, Halifax, Nova Scotia, Canada, B3H 1X5, E-mail: vrafuse@dal.ca; or Dr. James P. Fawcett, Department of Pharmacology, Sir Charles Tupper Medical Building, Dalhousie University, Halifax, Nova Scotia, Canada, B3H 1X5, E-mail: jim.fawcett@dal.ca.

DOI:10.1523/JNEUROSCI.4932-09.2010

Copyright $\odot 2010$ the authors $\quad 0270-6474 / 10 / 306595-12 \$ 15.00 / 0$
}

chick and mice indicate that LIM homeodomain genes mediate these precise trajectories by regulating the expression of downstream guidance molecules. For example, Lim1 expression in LMCl motoneurons leads to the upregulation of EphA4 (Kania and Jessell, 2003; Kramer et al., 2006), causing LMCl axons to project away from ephrinA5-expressing cells in the ventral limb mesenchyme (Helmbacher et al., 2000; Eberhart et al., 2002). EphB expression by Isl1/2-positive (Isl1/2 ${ }^{+}$) LMCm motoneurons causes them to project ventrally away from ephrin- $\mathrm{B}^{+}$cells in limb dorsum (Luria et al., 2008). Finally, Lhx3-expressing MMCm motoneurons grow toward fibroblast growth factor 8 (FGF8) (Shirasaki et al., 2006), which is expressed, at least at the mRNA level, in the lateral region of the myotome at the anterior and posterior margins of the somite (Crossley and Martin, 1995).

Despite these advancements, the intracellular signaling pathways mediating motor axons guidance downstream of receptor activation remains elusive. In part, this is because individual motoneuron subpopulations are difficult to isolate, making characterization of signaling pathways within a single population challenging. In comparison, pure populations of sensory and sympathetic neurons can readily be isolated based on neurotrophin dependency. This ability has led to the identification of several intracellular signaling pathways mediating axon growth (Glebova and Ginty, 2005). For example, NGF promotes branch formation in sensory neurons by activating the phosphoinositide-3 kinase (PI3K/Akt)-dependent pathway (Gallo and Letourneau, 1998), whereas BDNF induces axonal outgrowth from sympathetic neurons by activating both PI3K/ Akt and mitogen-activated protein kinase (MAPK) signaling pathways (Atwal et al., 2000).

Although subpopulations of motoneurons cannot be easily purified from embryos, recent studies have shown that mouse embryonic stem (ES) cells can be directed to differentiate into a 
pure population of $\mathrm{Lhx} 3^{+} \mathrm{MMCm}$ motoneurons (Wichterle et al., 2002; Soundararajan et al., 2006, 2007). Here, we use this unique population to show that MMCm motor axon guidance in vitro is mediated through MAPK/extracellular signal-regulated kinase (ERK) signaling pathway downstream of FGF8 activation of FGF receptor 1 (FGFR1). Furthermore, we used ES cellderived motoneuron/chick chimeras to show that this signaling pathway is specifically required for guidance at a distinct choice point in the periphery. Finally, we use information from this novel model system to show that proper guidance of endogenous chick MMCm motor axons requires activation of the same signaling pathway.

\section{Materials and Methods}

ES cell culture. Unless otherwise noted, HBG3 mouse ES cells (a kind gift from Dr. T. Jessell, Columbia University, New York, NY) were used throughout this study. HBG3 ES cells express enhanced green fluorescent protein (eGFP) under control of the mouse Hb9 promotor (Wichterle et al., 2002). Hb9 is a homeodomain expressed by all postmitotic somatic motoneurons, and thus eGFP expression can be used to identify ES cells that differentiated into motoneurons (Wichterle et al., 2002; Miles et al., 2004). Wild-type 129 ES cells were acquired from Open Biosystems, whereas FGFR1 $1^{\Delta t m k-1-}$ and FGFR ${ }^{\Delta t m k+/-}$ ES cells were a kind gift from Dr. Janet Rossant (University of Toronto, Toronto, Ontario, Canada) (from here on simply referred to as FGFR1 ${ }^{-1-}$ and FGFR $1^{+/-}$, respectively).

ES cells were expanded and maintained using methods described previously (Wichterle et al., 2002; Soundararajan et al., 2006). Briefly, ES cells were allowed to proliferate on mitomycin C (Sigma) treated primary mouse embryonic fibroblasts in medium containing DMEM with 4500 $\mathrm{mg} / \mathrm{L}$ glucose and $2250 \mathrm{mg} / \mathrm{L} \mathrm{Na}$-bicarbonate supplemented with nonessential amino acids, nucleosides (all from Specialty Media), $0.1 \mathrm{~mm}$ $\beta$-mercaptoethanol (Sigma), 2 mM L-glutamine (Invitrogen), penicillin/ streptomycin (Invitrogen), 10\% FBS (HyClone), and $1000 \mathrm{U} / \mathrm{ml}$ leukemia inhibitory factor (Millipore Bioscience Research Reagents). Two days later, the ES cells were transferred to DFK10 medium, in which they formed free-floating cell aggregates called embryoid bodies. DFK10 medium consisted of a 1:1 mixture of DMEM/F-12 media supplemented with penicillin/streptomycin ( $1 \%$ by volume; Sigma), N2 (2.4\% by volume; Invitrogen), glucose (4500 mg/L), L-glutamine (200 mM), heparin ( $1 \mathrm{U} / \mu \mathrm{l}$; Sigma), and $\beta$-mercaptoethanol (0.1 mm; Sigma).

ES cells were directed to differentiate into motoneurons as described previously (Soundararajan et al., 2007). Briefly, sonic hedgehog (Shh) expressing HEK293 cells (293 EcR-Shh cells; obtained from American Type Culture Collection) were attached to the external bottom surface of collagen-coated membrane inserts ( $3 \mu \mathrm{m}$ pore size; catalog \#3494; Corning) placed in wells containing DFK10 media. $293 \mathrm{EcR}-\mathrm{Sh}$ cells produce Shh when treated with ponesterone A (PA) because they carry an integrated construct for the expression of Shh under ecdysone-inducible control (Cooper et al., 1998). After $2 \mathrm{~d}$ in vitro (DIV), embryoid bodies containing mycoplasma-free ES cells were placed inside the inserts in which they loosely attached to the internal bottom surface. The media was supplemented with retinoic acid (RA) $(1 \mu \mathrm{M})$ and PA $(21.5 \mu \mathrm{M})$ to differentiate the ES cells into MMCm motoneurons. Differentiated ES cell-derived motoneurons were harvested from the membrane inserts as cell clusters after 5 DIV.

Collagen gels. Three dimensional (3-D) gels were prepared from rat tail collagen (BD Biosciences). Briefly, laminin/poly-D-lysine (BD Biosciences) coated coverslips were coated with $15 \mu \mathrm{l}$ of collagen as a base and placed in a humidified, $37^{\circ} \mathrm{C}$ incubator. Fifteen minutes later, ES cell-derived motoneurons were quickly inserted into $70 \mu \mathrm{l}$ of additional collagen placed on top of the base. The gels were returned to the incubator for 20 min before the addition of the DFK10 media, with or without FGF8 (FGF8b; 100 ng/ml; R \& D Systems) or FGF10 (100 ng/ml; R\&D Systems). In some experiments, ES cell-derived MMCm motoneurons were flanked with heparin beads (Sigma) incubated previously with recombinant FGF8 (FGF8b; $2 \mu \mathrm{g} / \mathrm{ml}$; R \& D Systems) or FGF10 $(2 \mu \mathrm{g} / \mathrm{ml}$; $\mathrm{R} \& \mathrm{D}$ Systems) for $3 \mathrm{~h}$. When noted, the DFK10 media containing one of the two FGFs was supplemented with SU5402 (12.5 $\mu$ M; Calbiochem). Finally, in some studies, ES cell-derived motoneurons were treated with FGF8 (100 ng/ml) and $25 \mu \mathrm{M} \mathrm{LY294002} \mathrm{(Biomol)} \mathrm{or} 100 \mu \mathrm{M}$ PD98059 (Biomol) to inhibit the PI3K/Akt and MAPK/ERK signaling pathways, respectively.

After $24 \mathrm{~h}$, cultures were fixed in 4\% paraformaldehyde. 3-D collagen gels used for immunocytohistochemistry were washed three times with PBS containing 1\% Triton X-100 (PBTx; Sigma), incubated with a $\beta$-III tubulin monoclonal IgG antibody (1:10,000; Covance) and 10\% goat serum for $2 \mathrm{~d}$ at $4^{\circ} \mathrm{C}$ in $1 \%$ PBTx, washed three times with PBTx, and incubated with a cyanine 3 (Cy3)-conjugated goat anti-mouse IgG secondary antibody (Jackson ImmunoResearch) for $1 \mathrm{~d}$. The gels were placed on slides in Vectashield mounting medium (Vector Laboratories) to prevent fading and coverslipped. Images were captured using a laserscanning confocal microscope (LSM 510; Carl Zeiss).

The degree of neurite outgrowth was scored and quantified using a $0-4$ scale. The reference images used for scoring are illustrated in supplemental Figure 1 (available at www.jneurosci.org as supplemental material). Preferential neurite outgrowth toward FGF8-loaded beads was scored and quantified using a $1-4$ scale, in which 1 represented no preferential outgrowth toward the FGF8-loaded beads, whereas 2-4 represented progressive more robust outgrowth toward the source of FGF8 (supplemental Fig. 1, available at www.jneurosci.org as supplemental material). In both cases, scoring was performed by someone blind to the experimental conditions.

Immunocytochemistry. To examine the expression of homeodomain transcription factors, ES cell-derived MMCm motoneurons were cultured on a matrigel (BD Biosciences) substrate in DFK10 media for $1 \mathrm{~d}$ before they were fixed in $4 \%$ paraformaldehyde for $10 \mathrm{~min}$. After several washes with PBS, the cells were incubated with a primary antibody containing $10 \%$ goat serum at $4^{\circ} \mathrm{C}$ for $12 \mathrm{~h}$. The following primary monoclonal IgG antibodies were used: anti-Lim1/2 (1:2), anti-Lhx3 (1:50), and anti-Isl-1/2 (1:5) (all three from the Developmental Studies Hybridoma Bank), Hb9 (1:10,000; a kind gift from Dr. T. Jessell). After several washes with PBS, the cells were incubated in a Cy3-conjugated goat anti-mouse secondary antibody (1:500; Jackson ImmunoResearch) at room temperature for $2 \mathrm{~h}$. Slides were mounted in a 50\% glycerol/PBS mixture containing $0.03 \mathrm{mg} / \mathrm{ml} \rho$-phenylenediamine to prevent fading and coverslipped, and images were captured using a laser-scanning confocal microscope or an Axiovert fluorescent microscope (Carl Zeiss).

In ovo transplantation and immunohistochemistry. Fertile eggs (Truro) from white leghorn chicken (Gallus domesticus) were incubated at $37^{\circ} \mathrm{C}$ in a humidified incubator. Under sterile conditions, Hamilton and Hamburger $(\mathrm{HH})$ stage 17 (Hamburger and Hamilton, 1951) [at approximately embryonic day 2.5 (E2.5)] chicken embryos were exposed using a dental drill to open the shell. Neutral red (0.1\%; Sigma) in sterile saline was used to aid in the visualization of the vitelline membranes, which were subsequently opened to allow access to the embryo. Using a flamed sharpened tungsten knife $(0.077 \mathrm{~mm}$ wire; World Precision Instruments), an incision spanning one somite was made in the neural tube to expose the lumen at T7-L1, after which the ependymal layer within the ventral region of the neural tube was disrupted with a pulled glass electrode. Approximately $120 \mathrm{eGFP}^{+} \mathrm{ES}$ cell-derived MMCm motoneurons were transplanted into ventral region of the neural tube. We chose this number of cells because our previous studies (Soundararajan et al., 2006, 2007) showed that $100 \%$ of the transplanted ES cell-derived motoneurons innervated epaxial muscles when $\sim 100$ motoneurons were transplanted into the neural tube at this stage in development. If $>250 \mathrm{ES}$ cell-derived MMCm motoneurons are transplanted in ovo, many will mistarget to the limbs (Soundararajan et al., 2006). The eggs were then sealed and returned to the incubator.

Embryos were killed at $\mathrm{HH}$ stage 31 (i.e., $\sim 5 \mathrm{~d}$ later), eviscerated, ventral laminectomized, fixed in 4\% paraformaldehyde/PBS for $1 \mathrm{~h}$, washed several times in PBS, and finally incubated in PBS overnight at $4^{\circ} \mathrm{C}$. The embryos were immersed in $30 \%$ sucrose/PBS for $2 \mathrm{~h}$ at $4^{\circ} \mathrm{C}$, mounted in OCT (Tissue Tek), and frozen at $-80^{\circ} \mathrm{C}$. Coronal sections $(30 \mu \mathrm{m})$ were cut using a cryostat and dried on Superfrost slides (Fisher Thermo Scientific). Sections were washed for $20 \mathrm{~min}$ in PBS before incubating overnight, at $4^{\circ} \mathrm{C}$, in a primary antibody diluted in PBS contain- 
ing $10 \%$ normal goat serum (Sigma) with $0.3 \%$ Triton X-100. The following primary mouse $\operatorname{IgG}$ antibodies were used: anti-Isl1/2 (1:5), anti-Lim1/2 (1:2), anti-Lhx3 (1:50) (all three from the Developmental Studies Hybridoma Bank), anti-pan-neural cell adhesion molecule (NCAM) (1:10,000; BD Pharmingen), and anti- $\beta$-III tubulin (1:5000; Covance). Rabbit polyclonal IgG antibodies used included: anti-FoxP1 (1:10,000; Abcam), anti-Lhx3 (1:500; Abcam), and anti-GFP (1:1000; Millipore Bioscience Research Reagents). After washing in PBS, sections were incubated in Cy3-conjugated goat anti-mouse, Cy2-conjugated goat anti-rabbit secondary antibody (1:500; Jackson ImmunoResearch), and Alexa Fluor 647 donkey anti-rabbit (1:500; Invitrogen) at room temperature for $2 \mathrm{~h}$ and mounted in 50\% glycerol/PBS mixture containing $0.03 \mathrm{mg} / \mathrm{ml} \rho$-phenylenediamine. Confocal images were captured using a laser-scanning confocal microscope, and confocal orthogonal images were rendered using the Carl Zeiss LSM image browser software.

Western blot. Approximately 1 million free-floating ES cell-derived MMCm motoneurons were incubated in DFK10 media for 15 min with or without recombinant FGF8 (50 ng/ml; R \& D Systems) or FGF10 (50 $\mathrm{ng} / \mathrm{ml}$; R \& D Systems). In some noted experiments, the PI3K/Akt or MAPK/ERK signaling pathway was inhibited by incubating the ES cellderived motoneurons with $25 \mu \mathrm{M}$ LY294002 (Biomol) or $75 \mu \mathrm{M}$ PD98059 (Biomol), respectively, for 15 min before the addition of FGF8 or FGF10 as indicated. Cells were washed once with PBS and lysed in ice-cold TBS lysis buffer (0.5 м Tris, pH 7.4, 0.5\% NP-40, $150 \mathrm{~mm} \mathrm{NaCl}, 10 \%$ glycerol, and protease inhibitors). Lysates of each sample $(20 \mu \mathrm{g})$ were boiled with sample buffer ( 0.5 м Tris, $\mathrm{pH} 6.8$, glycerol, $10 \%$ SDS, 2-mercaptoethanol, and $1 \%$ bromophenol blue), separated using a $10 \%$ SDS-PAGE gels, transferred to an Immobilon-P membrane (Millipore Corporation), and incubated overnight at $4^{\circ} \mathrm{C}$ with antibodies to phosphorylated ERK (pERK) (1:10,000; Santa Cruz Biotechnology), or p-Akt (1:1000; Ser-473; Cell Signaling Technology). The membranes were incubated with a horseradish peroxidase-conjugated goat anti-mouse IgG secondary antibody for $2 \mathrm{~h}$ at room temperature and detected using enhanced chemiluminescence (GE Healthcare). The blots were later stripped and reprobed with primary antibodies against ERK (1:10,000; Santa Cruz Biotechnology) or Akt (1:1000; Cell Signaling Technology) and visualized as described above.

Reverse transcription-PCR. Total RNA from $\sim 1$ million ES cell-derived $\mathrm{MMCm}$ motoneurons was isolated using an RNeasy Mini extraction kit (Qiagen). One hundred nanograms of total RNA in a reaction volume of 20 $\mu \mathrm{l}$ was reverse transcribed at $50^{\circ} \mathrm{C}$ for $1 \mathrm{~h}$ using reverse transcription (RT)only OMNI RT enzyme kit (Qiagen). PCR was performed using $1 / 10$ of the RT reaction mix. The following primers were used: FGFR1 forward, $5^{\prime}$ GCTGACTCTGGCCTCTACGCT-3'; FGFR1, 5' - CAGGATCTCCACATACGGCAA-3'; FGFR2iiib forward, 5' -CCCATCCTCCAAGCTGGACTGCCT-3'; FGFR2iiib reverse, 5'-CAGAGCCAGCACTTCTGCATTG- $3^{\prime}$.

Infection of motoneurons with adenovirus. ES cell-derived MMCm motoneurons were plated on matrigel-coated coverslips for $24 \mathrm{~h}$ in DFK10 media. Adenovirus expressing constitutively activated MAP kinase kinase (AdMEK-CA::GFP) (kindly provided by Dr. Freda Miller, University of Toronto, Toronto, Canada) or GFP (AdGFP) (kindly provided by Dr. Craig McCormick, Dalhousie University, Halifax, Nova Scotia, Canada) were added to the cultures at 100 multiplicities of infection $\left(3.75 \times 10^{8} \mathrm{pfu} /\right.$ $\mathrm{ml}$ ). Along with the addition of adenovirus, the cultures were supplemented with glial-derived neurotrophic factor $(20 \mathrm{ng} / \mathrm{ml}$; Millipore Corporation) and ciliary neurotrophic factor $(10 \mathrm{ng} / \mathrm{ml}$; Millipore Corporation). After $24 \mathrm{~h}$ of incubation, the ES cell-derived MMCm motoneurons were resuspended in fresh DFK10 media before transplantation into the developing spinal cord of $\mathrm{HH}$ stage 17 chick embryos (see above for detailed description of transplantation procedures and immunohistochemistry).

In ovo electroporation. Neural tube electroporations were performed on HH stage 16.5 chick embryos because MMCm motoneurons supplying LS1-LS3 are born at this stage in development (Hollyday and Hamburger, 1977). Briefly, embryos were exposed, vitelline membranes were removed, and $5 \mu \mathrm{g} / \mu \mathrm{l}$ solution of plasmid DNA mixed in $0.2 \%$ phenol red was injected into the lumen of the neural tube. Electrodes were po- sitioned at the anterior aspect of the hindlimb bud at the presumptive LS1-LS3 region (see Fig. 7A). To transfect MMCm neurons, the positive electrode was angled ventrally, whereas the negative electrode was placed dorsally. Electroporation was performed using a BTX 830 electroporator (settings: $15 \mathrm{~V}, 50 \mathrm{~ms}$ duration, five pulses at $1 \mathrm{~Hz}$; BTX; Harvard Apparatus). Embryos were transfected with hemagglutinin (HA)-tagged constitutively active MEK (MEK-CA::HA; kindly provided by Dr. Natalie Ahn, University of Colorado, Boulder, CO) or pCAX::GFP (a chick $\beta$-actin promoter fused to the cytomegalovirus immediate-early enhancer to drive eGFP expression; kindly provided by Dr. Catherine Krull, University of Michigan, Ann Arbor, MI).

Retrograde labeling of motoneurons and quantification of axonal misprojections. Electroporated embryos were quickly decapitated and eviscerated at $\mathrm{HH}$ stage 31 . Skin was removed to expose the thigh muscles, and a ventral laminectomy was performed in cold, well oxygenated Tyrode's solution. Thigh muscles, innervated by LS1-LS3, were injected with 1\% Alexa Fluor 594-conjugated cholera toxin B (CTb) (see Fig. 7B) (Invitrogen). The spinal cord hindlimb preparations were then incubated in well oxygenated Tyrode's solution maintained at $33^{\circ} \mathrm{C}$ for $7 \mathrm{~h}$ to allow for retrograde transport to motoneurons. The embryos were fixed immediately in $4 \%$ paraformaldehyde, cut, and immunostained for Lhx3 and HA or FoxP1 and HA. The number of transfected MMCm motoneurons misprojecting to thigh muscles was quantified by counting all of the Lhx $3^{+}$neurons labeled with CTb and coexpressing HA (or GFP for the pCAX::GFP transfected embryos) in the spinal cord between LS1 and LS3.

\section{Results}

The ability to manipulate and expose distinct classes of neurons to purified guidance cues in vitro has greatly facilitated the discovery of axon guidance molecules, their receptors, and downstream signaling pathways mediating directional growth. Unlike sensory (Messersmith et al., 1995), sympathetic (Atwal et al., 2000), spinal commissural (Kennedy et al., 1994), and retinal ganglion (Barres et al., 1988) neurons, different pools of motoneurons cannot be readily isolated based on neurotrophin dependency, distinct anatomy, or immunopanning. This limitation has hindered the discovery of intracellular signaling pathways mediating motor axon guidance. Interestingly, recent studies indicate that mouse ES cell-derived motoneurons represent a distinct subpopulation of motoneurons that may be used to study axon guidance. In particular, mouse HBG3 ES cells differentiate into a single population of $\mathrm{Lhx} 3^{+}$motoneurons when treated in culture with RA and an Shh agonist (Wichterle et al., 2002; Soundararajan et al., 2006) or RA and Shh (Soundararajan et al., 2007). HBG3 ES cells differentiate into $\mathrm{eGFP}^{+}$motoneurons because they express eGFP under control of the mouse Hb9 promotor (Wichterle et al., 2002). When transplanted into the neural tube of $\mathrm{HH}$ stage 17 chick embryos, $\mathrm{eGFP}^{+}$ES cell-derived motoneurons continue to express Lhx3, migrate to the MMCm, develop passive membrane properties similar to endogenous chick MMCm motoneurons, upregulate adhesion molecules typical of MMCm neurons, and exclusively project axons to epaxial muscles (Soundararajan et al., 2006, 2007), the normal target of MMCm motoneurons. Together, these studies indicate that mouse ES cell-derived motoneurons acquire behavioral and cellular phenotypes typical of MMCm motoneurons (Soundararajan et al., 2006), making them ideal for studying signaling pathways involved in MMCm axon guidance. However, before they can be used for this purpose, it is essential to determine whether they respond to axons guidance cues in a manner appropriate for MMCm motoneurons. 
ES cell-derived MMCm motoneurons express FGFR1 and respond to FGF8 MMCm motor axons are attracted to epaxial muscle primordial cells (i.e., the dermomyotome) flanking the dorsal aspect of the vertebral column during development (Kablar and Rudnicki, 1999). Similarly, ES cell-derived MMCm motoneurons selectively innervate epaxial muscles when transplanted in ovo (Soundararajan et al., 2006, 2007). Several lines of evidence indicate that this attraction is mediated, at least in part, through FGFR signaling. First, mRNA for FGF8 is expressed in the myotome (Crossley and Martin, 1995; Stolte et al., 2002). Second, expression of the FGF8 receptor, FGFR1, is restricted to MMCm during development (Shirasaki et al., 2006). Finally, genetic deletion of FGFR1 in neuronal cells during motoneurogenesis leads to MMCm motor axon guidance defects (Shirasaki et al., 2006). If ES cell-derived MMCm motoneurons use the same guidance mechanisms as their endogenous counterparts, it seemed reasonable to assume that they will express FGFR1 and be attracted to FGF8. To address these issues, we first used RT-PCR to examine FGFR1 expression in ES cell-derived MMCm motoneurons. As expected, ES cell-derived MMCm motoneurons contained mRNA for FGFR1 (Fig. 1A), indicating that they express the appropriate receptor for FGF8-mediated axon guidance. Undifferentiated ES cells and 3T3 cells were included as positive controls because both express FGFR1 (Mathieu et al., 1995) (Fig. 1A).

To determine whether FGF8 enhances neurite outgrowth through FGFRs, we cultured spheres of ES cell-derived motoneurons in 3-D collagen gels for $24 \mathrm{~h}$ in media alone or in the presence of bathapplied FGF8 (100 ng/ml). Figure 1 shows that the number and length of $\mathrm{eGFP}^{+}$neurites was greatest in cultures containing FGF8 (Fig. $1 B, E$ ). Neurite outgrowth was significantly attenuated when SU5402 (12.5 $\mu \mathrm{M})$, an FGFR1/FGFR3 antagonist, was added to the cultures containing FGF8 (Fig. $1 D, E$ ), indicating that the induced growth was mediated through FGFR1/FGFR3. Neurite outgrowth, from 11 separate series of experiments, was scored using a $0-4$ scale, in which 0 represented the least amount of outgrowth (Fig. 1E) (for details, see Materials and Methods and supplemental Fig. 1, available at www.jneurosci.org as supplemental material). ANOVA ( $n=11$ for each condition) analysis of the quantified growth scores revealed that FGF8-treated ES cell-derived motoneurons had significantly more outgrowth compared with media alone $(p<0.05)$ or cells treated with FGF8 and SU5402 $(p<0.05)$. Outgrowth from untreated ES cellderived motoneurons was not significantly different from those treated with FGF8 and SU5402. Together, these data suggest that our ES cell-derived motoneurons express FGFR1 and respond to FGF8.
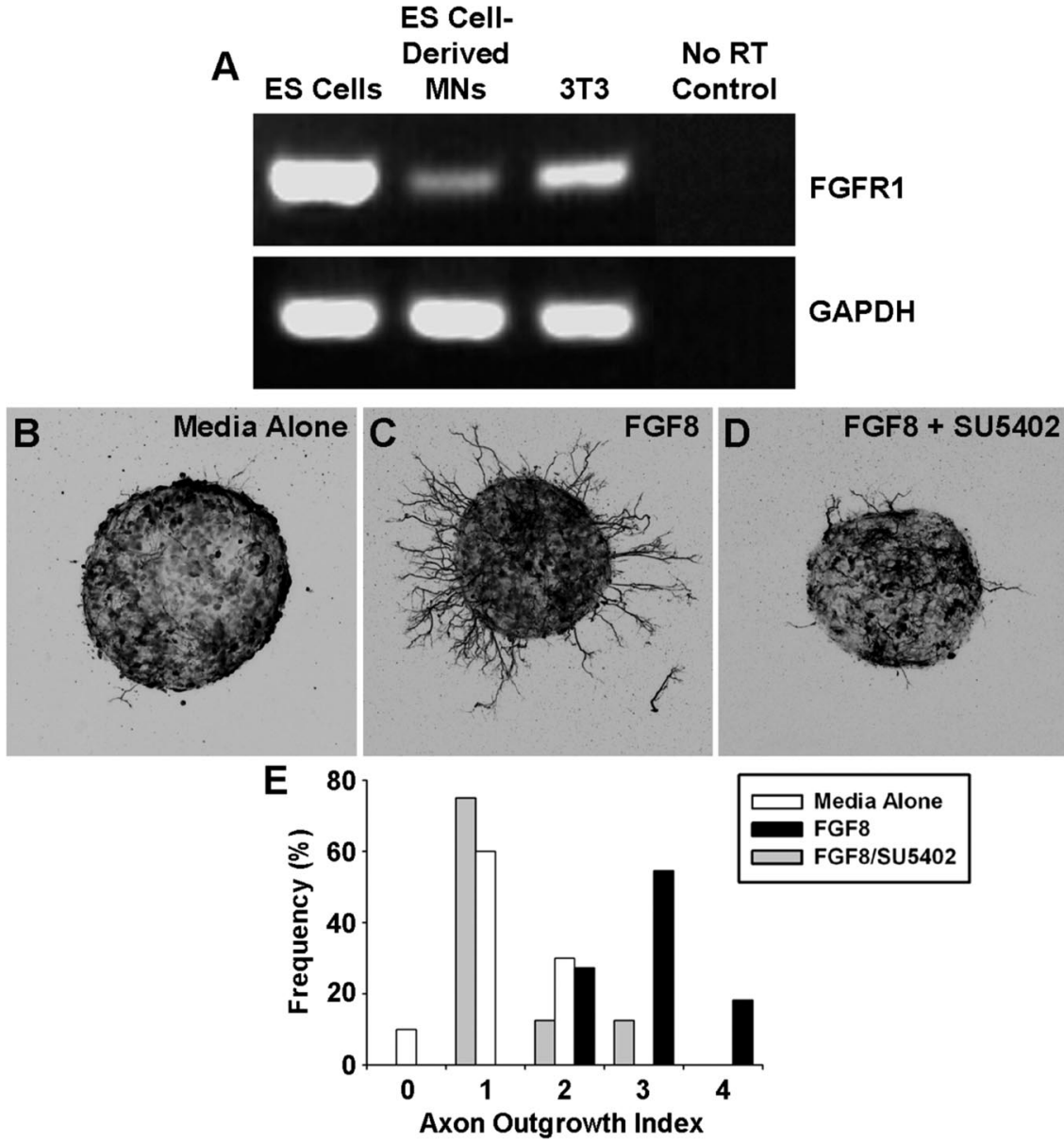

Axon Outgrowth Index

Figure 1. ES cell-derived MMCm motoneurons express FGFR1 and readily extend axons when exposed to the trophin FGF8. $\boldsymbol{A}$,

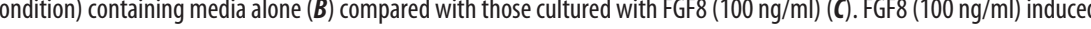
D). Pictures are $z$-stack collapsed confocal images in which the green fluorescence is shown as inverted black and white. $\boldsymbol{E}$ Quation of neurite outgrowth, using an outgrowth index [for details, see Materials and Methods and supplemental Fig. cell-derived motoneurons had significantly more outgrowth compared with media alone $(p<0.05)$ or cells treated with FGF8 and SU5402 ( $p<0.05$ ). Outgrowth from the latter two conditions was not significantly different from one another.

To determine whether FGF8 mediates axon targeting of MMCm motoneurons via activation of FGFR1, we first flanked HBG3 ES cell-derived MMCm motoneurons with FGF8 and FGF10-loaded heparin beads in 3-D collagen gels to generate opposing sources of FGFs. FGF10 was chosen as a useful negative control because it is expressed in limb mesenchyme but not the dermomyotome (Ohuchi et al., 1997). Figure 2 shows that ES cell-derived MMCm motoneurons preferentially extended neurites toward FGF8-loaded beads (Fig. $2 A, D$ ). To rule out the possibility that directed growth of axons toward the source of FGF8 was attributable to FGF10-mediated chemorepulsion, we performed another series of experiments in which ES cell-derived MMCm motoneurons were flanked by a single bead incubated previously in FGF8 or FGF10 ( $n=5$ for each condition). As expected, ES cell-derived MMCm motoneurons preferentially extended eGFP ${ }^{+}$axons toward the source of FGF8 in the 3-D collagen gels but showed little to no outgrowth when cultured in gels containing beads preincubated with FGF10 (supplemental Fig. 3, available at www.jneurosci.org as supplemental mate- 

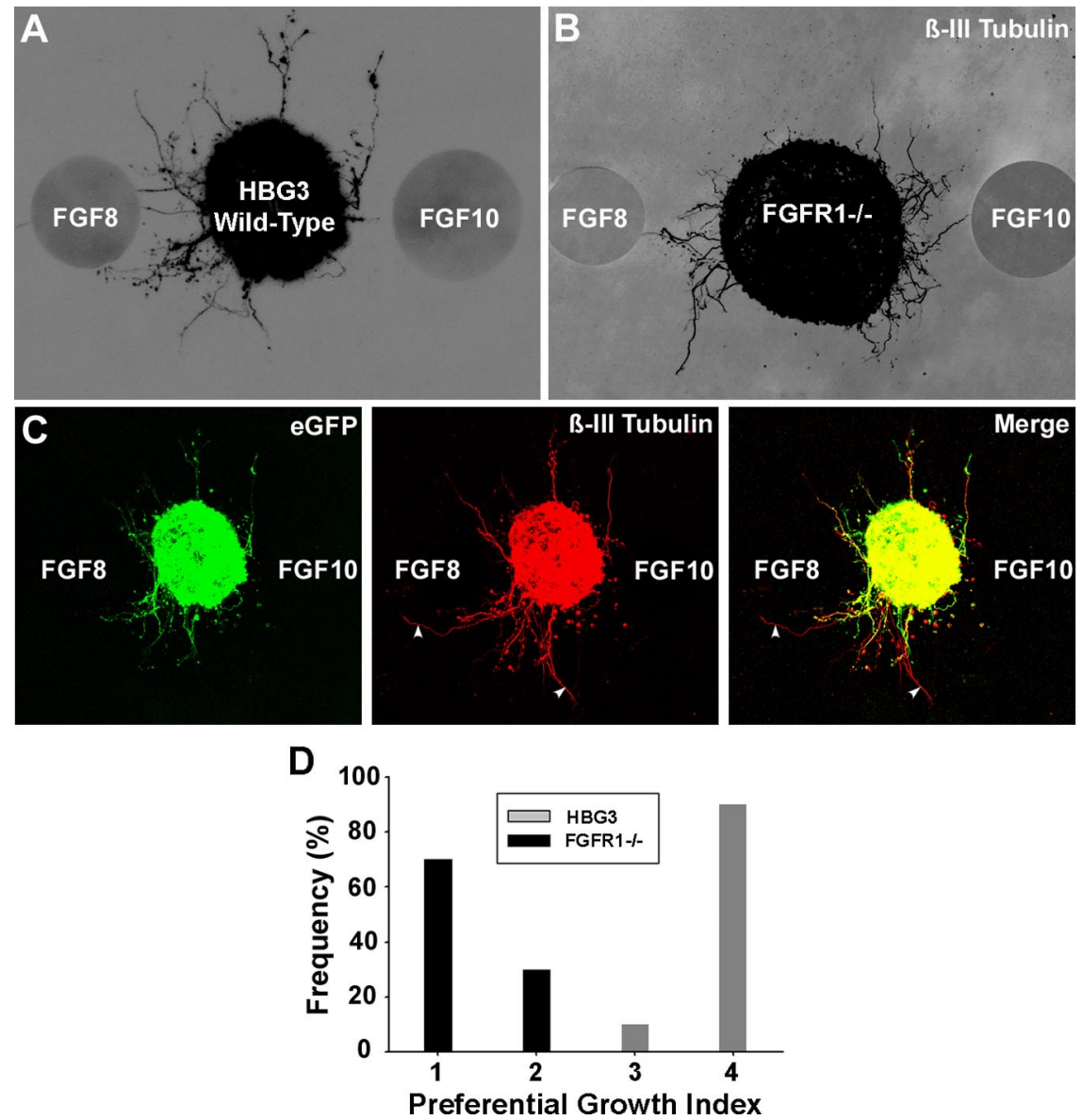

Figure 2. ES cell-derived MMCm motoneurons preferentially extend neurites toward FGF8 in 3-D collagen gels. $A, B$, ES cellderived MMCm motoneurons preferentially extended eGFP ${ }^{+}$neurites toward FGF8-loaded beads after $24 \mathrm{~h}$ in culture, although they were equidistant to FGF10-loaded beads (A). ES cell-derived motoneurons lacking $F G F R 1^{-/-}$, stained for $\beta$-III tubulin, did not show preference for either FGF8 or FGF10. Both images are a $z$-stack collapsed confocal image shown as an inverted black and white of the fluorescence. $C, z$-stack collapsed confocal images of the eGFP ${ }^{+}$ES cell-derived motoneurons, shown in $A$, immunolabeled for $\beta$-III tubulin. Merged image shows that the vast majority of neurites extending into the collagen are eGFP ${ }^{+}$and $\beta$-III tubulin $^{+}$. Two eGFP ${ }^{-} / \beta$-III tubulin ${ }^{+}$neurites are indicated with arrowheads. $\boldsymbol{D}$, Quantification of neurite outgrowth, using a preferential neurite outgrowth index (supplemental Fig. 2, available at www.jneurosci.org as supplemental material). Wild-type ES cell-derived motoneurons extended more neurites toward FGF8 compared with motoneurons lacking FGFR1 (ANOVA, $p<0.05$; $n=6$ for each condition).

rial). These results suggest that FGF10 is not a strong ES cellderived MMCm motoneurons chemorepellent.

To determine whether the preferential outgrowth was mediated through FGFR1, we performed a similar series of experiments using motoneurons derived from ES cells deficient in FGFR1 (Yamaguchi et al., 1994). To verify that FGFR1 ${ }^{-1-}$ ES cells differentiate into $\mathrm{Lhx} 3^{+}$motoneurons in a manner comparable with wild-type ES cells, we treated $\mathrm{HBG} 3, \mathrm{FGFR}^{+/-}$, and $F_{G F R}{ }^{-/-}$ES cells with RA/Shh for 5 DIV and then accessed them for $\mathrm{Hb} 9$ expression $1 \mathrm{~d}$ later. Our results showed that all three cell types differentiated into a comparable number of $\mathrm{Hb}^{+}$motoneurons (supplemental Fig. $4 A-C$, available at www.jneurosci. org as supplemental material). Furthermore, as reported for HBG3 ES cells (Wichterle et al., 2002; Soundararajan et al., 2006, 2007), $>95 \%(97.3 \% ; n=4)$ of motoneurons derived from FGFR1 ${ }^{-/-}$ES cells expressed Lhx3 (supplemental Fig. $4 D$, available at www.jneurosci.org as supplemental material), whereas only $2.5 \%(n=4)$ expressed Lim1 (supplemental Fig. $4 E$, available at www.jneurosci.org as supplemental material). These results indicate that ES cells lacking FGFR1 differentiate into Lhx $3^{+}$motoneurons with the same frequency as wild-type cells.
To examine whether MMCm motor axons lacking FGFR1 preferentially grow toward FGF8, we flanked ES cell-derived FGFR $1^{-1-}$ motoneurons with FGF8 and FGF10-loaded beads in 3-D gels for $24 \mathrm{~h}$ and then immunostained the cultures for $\beta$-III tubulin to observe neurite outgrowth, because $F G F R 1^{-/-}$cells do not express eGFP. As expected, ES cellderived motoneurons randomly extended axons toward both sources of FGFs (Fig. $2 B, D)$, supporting the view that FGF8 mediates MMCm motor axon guidance by activating FGFR1. This random growth was not attributed to differences in methods used to visualize axons (i.e., eGFP vs $\beta$-III tubulin immunostaining) because the vast majority of the B-III tubulin ${ }^{+}$ axons in the HBG3 cultures were also $\mathrm{eGFP}^{+}$(Fig. 2C).

\section{Transplanted ES cell-derived MMCm motoneurons lacking FGFR1 misproject axons toward the limbs} To more directly test a role for FGFR1 signaling in MMCm motor axon guidance, we transplanted FGFR1 ${ }^{-/-}$and HBG3 wild-type ES cell-derived motoneurons into the neural tube of $\mathrm{HH}$ stage 17 chick embryos ( $n=10$ for each group). FGFR1 $^{-/-}$ES cell-derived motoneurons do not express eGFP; therefore, we visualized transplanted neurons $5 \mathrm{~d}$ later $(\mathrm{HH}$ stage 31) using an antibody specific to mouse NCAM, an axonal marker that fails to cross react with chick proteins, in both experimental groups. In agreement with previous studies (Soundararajan et al., 2006, 2007), when $\sim 100 \mathrm{eGFP}^{+}$ES cellderived motoneurons are transplanted into the chick spinal cord, their cell bodies migrated to the MMCm (Fig. 3A, two yellow neurons), and their axons extended out of the spinal cord through the ventral root (Fig. $3 A, C$, arrow). From here, they later projected dorsally as part of the dorsal ramus (Fig. $3 A, C$, arrowhead) before innervating epaxial muscles (Fig. $3 A, C$, open arrowhead). Mouse ES cell-derived motoneurons coexpressing eGFP and mouse-specific NCAM appear yellow in Figure $3 A$. Because not all mouse ES cells differentiate into motoneurons when treated with Shh and RA (Wichterle et al., 2002; Soundararajan et al., 2006), the $\mathrm{NCAM}^{+} / \mathrm{eGFP}$-negative $\left(\mathrm{eGFP}^{-}\right.$) neurites in Figure $3 A$ are likely associated with non-motoneurons that differentiated during the Shh/RA differentiation protocol (Wichterle et al., 2002; Miles et al., 2004; Soundararajan et al., 2006, 2007). Although the identities of these neurons remain unknown, some of them are glutamatergic (Miles et al., 2004). Despite the presence of these "interneurons," all $\mathrm{NCAM}^{+}$ neurites exiting the spinal cord were $\mathrm{eGFP}^{+}$(Fig. $3 A$, yellow axons indicated by the arrows), indicating that they were motor axons from the transplanted HBG3 ES cell-derived motoneurons.

Transplanted ES cell-derived FGFR1 ${ }^{-/-}$motoneurons projected axons out of the spinal cord through the ventral root (Fig. 
3D), indicating that FGFR1-mediated signaling is not required for this type of directional growth. Although a few ES cell-derived $\mathrm{FGFR}^{-/-}$motoneurons correctly navigated to epaxial muscles as part of the dorsal ramus (Fig. $3 B, D$, arrowhead), many axons incorrectly projected into the limb as part of the ventral ramus (Fig. $3 B, D$, yellow arrow). Similar results were obtained when we pretreated HBG3 ES cell-derived MMCm motoneurons for 2 h with SU5402 (a tyrosine kinase inhibitor to block FGFR1 signaling) before transplanting them in ovo (supplemental Fig. 5, available at www.jneurosci. org as supplemental material) $(n=6)$. We noted that the amount of axonal defasculation at the spinal plexus was greater with this treatment (supplemental Fig. $5 C, D$, broad yellow arrow, available at www.jneurosci.org as supplemental material) (see Discussion). Together with the 3-D collagen gel experiments, these results indicate that ES cell-derived MMCm motor axons require FGFR1mediated signaling through FGF8 to correctly navigate to the dermomyotome.

FGF8 selectively activates MAPK/ERK signaling pathways in ES cell-

\section{derived MMCm motoneurons}

Because our ES cell-derived MMCm motoneurons use the same guidance mechanism as their endogenous counterparts (Shirasaki et al., 2006), we next wanted to investigate the intracellular signaling pathways activated downstream of receptor activation. Studies using purified sympathetic neuronal culture systems have shown that neurotrophins induce directional outgrowth through the PI3K/Akt and MAPK/ERK pathways (Zhou and Snider, 2006). To determine whether activation of similar pathways promote outgrowth of axons from MMCm motoneurons, we stimulated motoneurons derived from HBG3, FGFR $1^{+/-}$, and $F G F R 1^{-/-}$ES cells with FGF8 or FGF10 (both $50 \mathrm{ng} / \mathrm{ml}$ ) for $15 \mathrm{~min}$ and then probed the cell lysates with phosphorylation-specific ERK and Akt antibodies ( $n=8$ for each condition). Western blot analysis revealed that activated p-ERK was readily detectable in whole-cell lysates from FGF8-treated motoneurons derived from HBG3 and FGFR $1^{+/-} \mathrm{ES}$ cells but not FGFR1 ${ }^{-/-}$cells (Fig. 4). Furthermore, only basal levels of p-ERK were detected in motoneurons derived from HBG3, $\mathrm{FGFR}^{+/-}$, or FGFR1 ${ }^{-/-}$ES cells treated with either FGF10 or media alone (Fig. 4). Interestingly, motoneurons derived from all three ES cell lines expressed the same level of p-Akt expression (Fig. 4), indicating that this pathway was not further activated by FGF8. The basal level of Akt activation likely reflects this pathway's involvement in regulating neuronal survival (Dudek et al., 1997) in an FGF8independent manner.

Because FGF8 activated MAPK/ERK signaling, we next wanted to test whether FGFR1 activation of ERK was necessary to promote axonal outgrowth. To test this, we treated motoneurons derived from HBG3 ES cells with FGF8 in the presence or absence of the MEK inhibitor PD98059 (75 $\mu \mathrm{M})$ or the PI3K/Akt inhibitor LY294002 $(25 \mu \mathrm{M})(n=6$ for each condition). Figure $5 A$ shows that neurite outgrowth was dramatically attenuated in cultures treated with PD98059 compared with FGF8 treatment alone. As expected from our Western blot analysis, cultures treated with FGF8 and the Akt inhibitor LY294002 had little effect on outgrowth compared with cultures treated with FGF8 alone (Fig. $5 A$ ). To confirm that the inhibitors blocked activation of the MAPK/ERK and PI3K pathways at the concentrations used, we treated HBG3 ES cell-derived motoneurons with FGF8 alone or in combination with PD98059 or LY294002. The inhibitors were added 20 min before a 15 min pulse with FGF8 (100 ng/ml). As anticipated, p-ERK and p-Akt were dramatically downregulated in the presence of PD98059 and LY294002, respectively (Fig. 5B). Together, these results indicate that FGF8 activation of FGFR1 

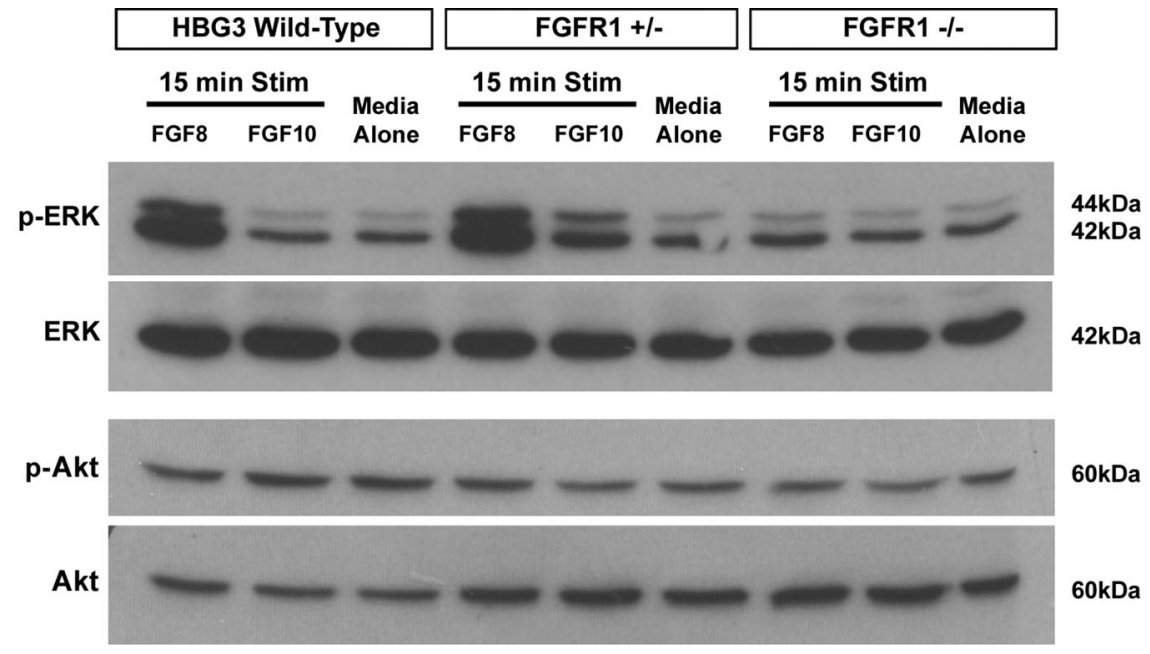

Figure 4. FGF8 phosphorylates ERK in motoneurons derived from $\mathrm{HBG} 3$ and $F G F R 1^{+/-}$but not $F G F R 1^{-1-}$ ES cells. A representative Western blot loaded with equal amounts of whole-cell lysate from motoneurons derived from $\mathrm{HBG3}, \mathrm{FGFR} 1^{+/-}$, and FGFR1 ${ }^{-/-}$ES cells treated for $15 \mathrm{~min}$ with FGF8 $(50 \mathrm{ng} / \mathrm{ml})$, FGF10 $(50 \mathrm{ng} / \mathrm{ml})$, or media alone. p-ERK (1st row) and p-Akt (3rd row). Blots were reprobed with an antibody against total ERK (2nd row) or total Akt (4th row).
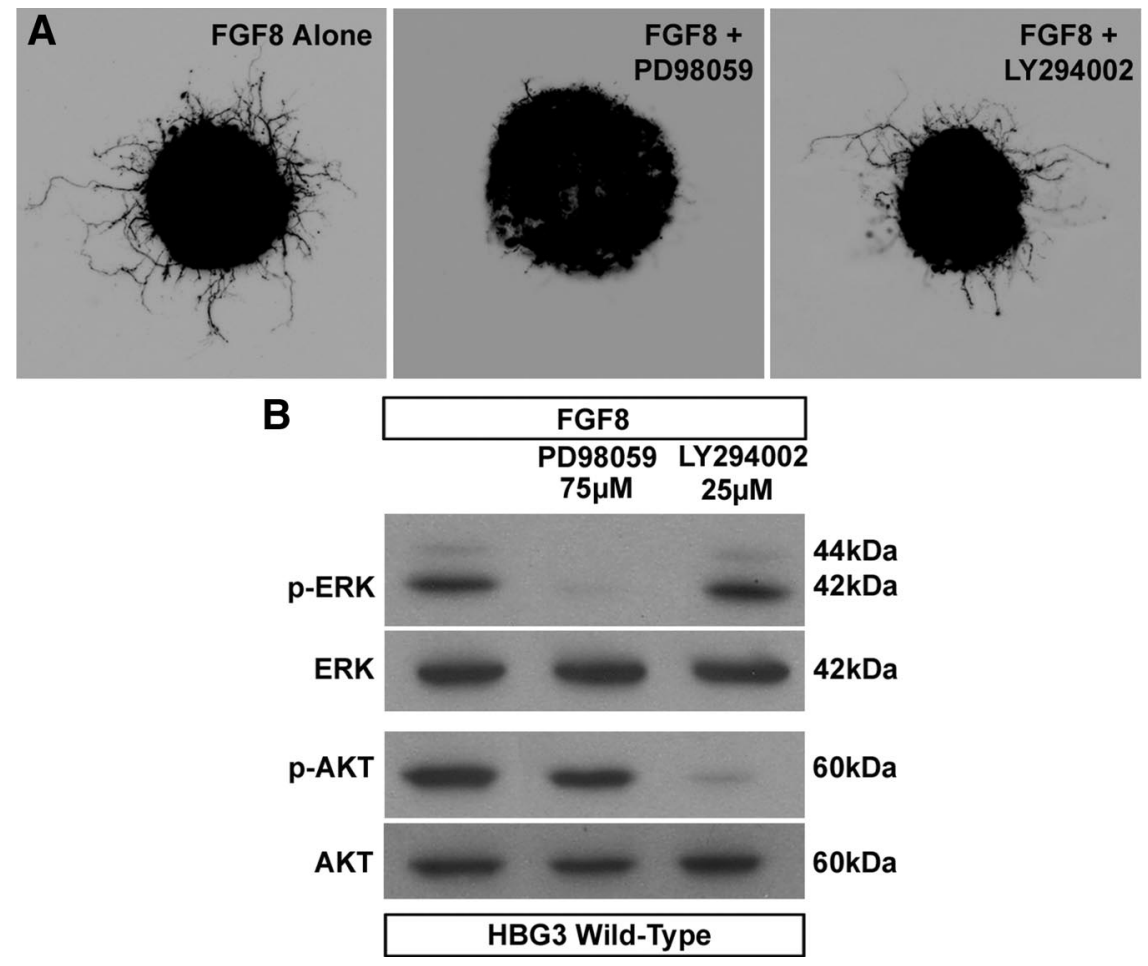

Figure 5. Inhibition of the MAPK/ERK signaling pathway attenuates FGF8-mediated axonal outgrowth. A, z-stack collapsed confocal images of HBG3 ES cell-derived MMCm motoneurons treated for $12 \mathrm{~h}$ with FGF8 alone or in the presence of $75 \mu \mathrm{M}$ PD98059 or $25 \mu \mathrm{m}$ LY294002. Axonal outgrowth was dramatically attenuated in cultures containing FGF8 and PD98059 compared with those treated with FGF8 alone or with FGF8 and LY294002. Pictures are shown as inverted black and white images of the green fluorescence. $\boldsymbol{B}$, Western blot analysis shows that the concentrations of PD98058 and LY294002 used in the outgrowth assays inhibited phosphorylation of ERK and Akt, respectively. Neither inhibitor blocked phosphorylation of the kinase in the other pathway.

promotes neurite outgrowth from ES cell-derived MMCm motoneurons in vitro through MAPK/ERK.

\section{Constitutively activating MEK in ES cell-derived MMCm motoneurons causes mistargeting}

To further examine the role of MAPK/ERK signaling in MMCm motor axon guidance, we transduced $129 \mathrm{ES}$ cell-derived MMCm
$60 \mathrm{kDa}$

$60 \mathrm{kDa}$

motoneurons to express constitutively activated MEK using a bicistronic adenovirus vector (AdMEK-CA::GFP). As a control, another series of 129 ES cellderived $\mathrm{MMCm}$ motoneurons were transduced with a replication-deficient adenovirus expressing GFP (AdGFP). Twenty-four hours after transduction, the motoneurons were transplanted into the neural tube of $\mathrm{HH}$ stage 17 chick embryos. Five days later ( $\mathrm{HH}$ stage 31 ), the embryos were killed and processed for GFP and neurofilament immunohistochemistry to visualize transplanted and endogenous axons. Because GFP expression in infected neurons wanes over time, we also visualized the anatomy of the transplanted neurons using an antibody specific to mouse NCAM. As expected, transplanted AdGFP-infected ES cellderived $\mathrm{MMCm}$ motoneurons migrated to the MMCm (Fig. $6 C$, green dots), grew axons out of the spinal cord through the ventral root (Fig. $6 A, C$, arrow), and extended dorsally as part of the dorsal ramus (Fig. $6 B, C$, arrowhead), where they eventually innervated epaxial muscles (Fig. $6 C$, open arrowhead). Transplanted AdMEKCA::GFP-infected motoneurons also migrated to the MMCm (Fig. $6 F$, green dots) (high magnification of two cells expressing GFP and mouse NCAM are shown in supplemental Fig. 6, available at www. jneurosci.org as supplemental material) and correctly extended axons out of the spinal cord through the ventral root (Fig. 6D,F, arrow), indicating that MAPK/ERK signaling is not required for these processes. However, the pathway is clearly involved in $\mathrm{MMCm}$ motor axon targeting, because many of the axons misprojected through the dorsal root ganglion (DRG) (Fig. 6D, F, yellow arrowhead) or toward the limbs as part of the ventral ramus (Fig. $6 F$, yellow arrow) once they exited the spinal cord. In addition, a number of motor axons projecting toward the limbs became highly defasciculated and wandered randomly at the ventral ramus, where it trifurcates into three nerves (Fig. $6 E, C$; for anatomy, see short arrow on the contralateral side). Importantly, these three nerves normally contain axons from motoneurons residing in the LMC (Luria and Laufer, 2007). As observed with transplanted $F G F R 1^{-1-} \mathrm{MMCm}$ motoneurons, some AdMEK-CA::GFP-infected motor axons correctly projected around the DRG (Fig. $6 F$, arrowhead) and innervated the epaxial muscles (Fig. 6F, open arrowhead). Nonetheless, these results indicate that activation of the MAPK/ERK signaling pathway is essential for directional growth of transplanted MMCm motor axons once they exit the spinal cord. 


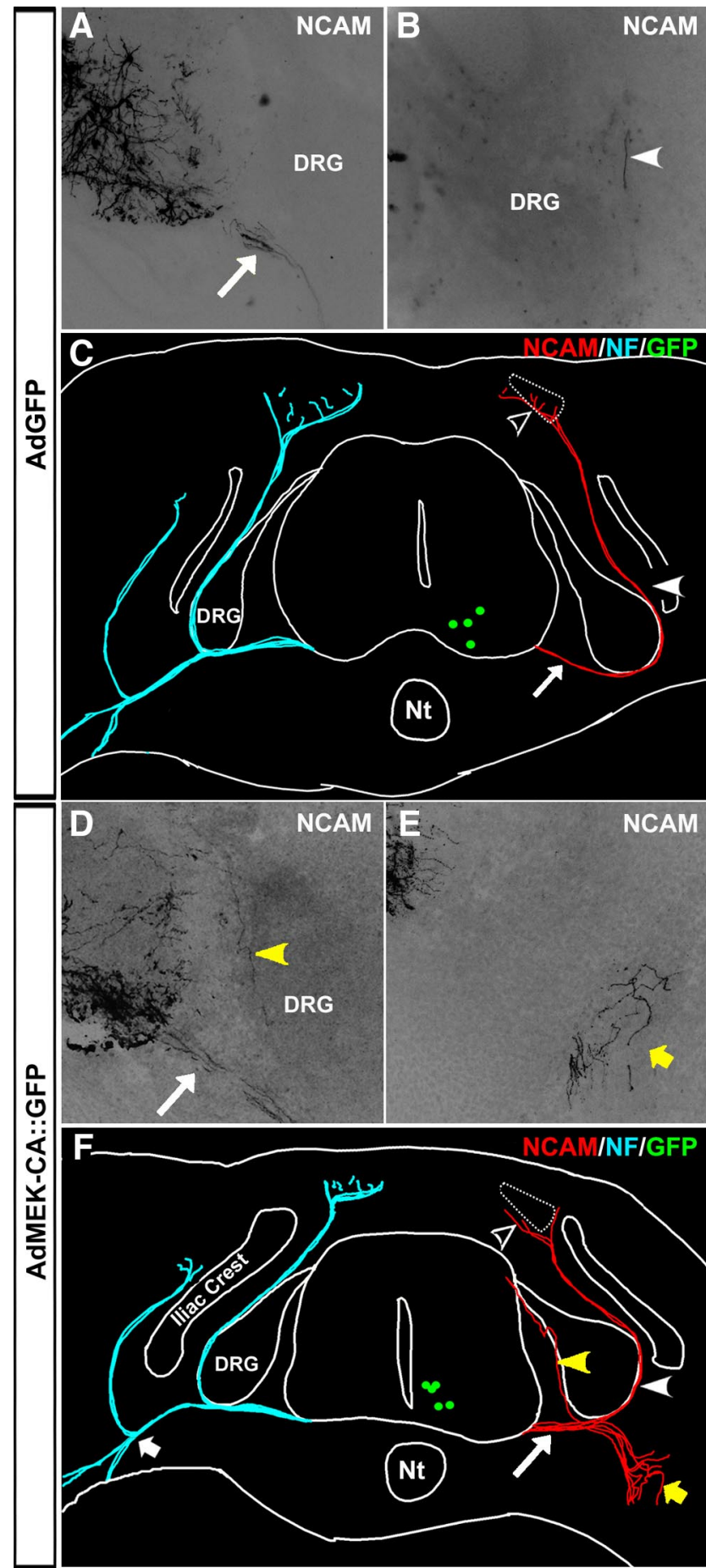

Figure 6. Constitutively activating MEK in transplanted ES cell-derived $\mathrm{MMCm}$ motoneurons causes axonal misprojections. $A, B$, Cross sections of the ventral horn $(\boldsymbol{A})$ and DRG $(\boldsymbol{B})$ from an $\mathrm{HH}$ stage 31 chick embryo transplanted with wild-type 129 ES cell-derived MMCm motoneurons infected with AdGFP. Sections were immunostained with an antibody specific to mouse NCAM. Transplanted AdGFP-infected MMCm motor axons extended out of the spinal cord through the ventral root $(\boldsymbol{A}$, arrow) and around the DRG, where they formed part of the dorsal ramus ( $\boldsymbol{B}$, arrowhead). $\boldsymbol{C}$, Neurolucida reconstruction of the embryo in $\boldsymbol{A}$ and $\boldsymbol{B}$ shows that all of the transplanted AdGFP-infected motor axons grew out of the neural tube through the ventral root (arrow), formed part of the dorsal ramus (arrowhead), and projected into the epaxial muscle (open arrowhead). For comparison, the projection patterns of the endogenous neurofilament (NF)-positive chick neurons are shown in blue on the contralateral side. Green dots represent transplanted motoneurons still expressing GFP at this stage in development. $\boldsymbol{D}, \boldsymbol{E}$, Cross sections of the ventral horn $(\boldsymbol{D})$ and ventral nerve $(\boldsymbol{E})$ from an HH stage 31 chick embryo transplanted with ES cell-derived MMCm motoneurons infected with AdMEK-CA::GFP. Sections stained as in $\boldsymbol{A}$ and $\boldsymbol{B}$. Axons from transplanted AdMEK-CA-infected $\mathrm{MMCm}$ motoneurons correctly
Constitutive activation of MEK causes MMCm motor axon guidance defects

ES cell-derived MMCm motoneurons selectively target epaxial muscles when transplanted into the neural tube of developing chick embryos. This directional growth is dramatically altered if signaling through FGFR1 is prevented or if differential activation of the MAPK/ERK signaling pathway is altered by constitutively activating MEK in the transplanted motoneurons. To determine whether signaling through the MAPK/ERK pathway is required for directional growth of endogenous MMCm motor axons, we electroporated HA-tagged constitutively active MEK (MEK-CA::HA) or a control pCAX::GFP plasmid DNA into the neural tube of chick embryos at the presumptive LS1LS3 region (Fig. 7A) when MMCm motoneurons are born $(\mathrm{HH}$ stage 16.5) (Hollyday and Hamburger, 1977) $(n=4$ for each condition). To determine whether transfected MMCm motoneurons misprojected axons ventrally, we used an in vitro spinal cord/hindlimb preparation and injected Alexa Fluor 594conjugated CTb into all thigh muscles innervated by LS1-LS3 spinal nerves (Fig. $7 B$ ) to selectively back-label motoneurons (Hanson and Landmesser, 2004). Figure $7 C$ shows a confocal image from a section of the ventral horn containing $\mathrm{GFP}^{+}$, $\mathrm{CTb}^{+}$, and $\mathrm{Lhx} 3^{+}$neurons $5 \mathrm{~d}$ after electroporation of pCAX: GFP. We noted that none of the $\mathrm{Lhx}^{+}$neurons transfected with pCAX::GFP (Fig. $7 C$, arrowheads) were $\mathrm{CTB}^{+}$in the control embryos. In contrast, spinal sections from embryos transfected with MEK-CA::HA contained several HA immunolabeled neurons that were $\mathrm{Lhx}^{+}$and $\mathrm{CTb}^{+}$(Fig. $7 \mathrm{D}$, arrowheads). None of the $\mathrm{HA}^{+}$ cells containing $\mathrm{CTb}$ were immunopositive for FoxP1, a marker of LMC motoneurons (Fig. 7E). On average, MEK-CA::HA transfected embryos contained $29.5 \pm 0.866$ (SEM of $0.8819 ; n=4$ ) CTblabeled cells coexpressing Lhx3 and HA. The MMCm in this same region of the spinal cord contained $26.7 \pm 2.60(n=4) \mathrm{CTb}$ negative cells that were immunopositive for both Lhx3 and HA. Consequently, approximately half of the MMCm motoneurons transfected with MEK-CA::HA misprojected into the limb. Together, these results indicate that MAPK/ERK activation, downstream of FGFR1, is necessary for MMCm motor axon guidance.

\section{Discussion}

Previous studies have shown that motoneurons derived from mouse ES cells differentiate into Lhx $3^{+}$motoneurons in vitro (Wichterle et al., 2002; Soundararajan et al., 2006) and exclusively project axons to epaxial muscles, the normal target for MMCm motoneurons, when transplanted into the neural tube of chick embryos (Soundararajan et al., 2006, 2007). This exclusivity in differentiation and growth behavior was exploited in the present study to identify the intracellular signaling mechanisms regulating the guidance of a select subpopulation of motoneurons during development. Specifically, we combined traditional in vitro analysis with a novel ES cell/chick embryo model system,

\section{$\leftarrow$}

extended out of the spinal cord through the ventral root ( $\boldsymbol{D}$, arrow). However, some axons misprojected into the DRG ( $\boldsymbol{D}$, yellow arrowhead), whereas others incorrectly extended toward the limb, where they defasciculated and wandered at the point where the nerve trifurcates into three branches ( $\boldsymbol{E}$, yellow arrow). $\boldsymbol{F}$, Neurolucida reconstruction of the embryo in $\boldsymbol{D}$ and $\boldsymbol{E}$ shows AdMEK-CA::GFP-infected motor axons extending out of the neural tube through the ventral root (arrow). Someaxons entered the DRG (yellow arrowhead) or misprojected toward the limb, where the branched extensively (yellow arrow). A few AdMek-CA::GFP-infected motoneurons correctly extended axons dorsally (arrowhead) to the epaxial muscle (open arrowhead). Projection patterns of the endogenous neurofilament-positive chick neurons are shown in blue on the contralateral side. Short arrow indicates site of ventral nerve trifurcation. Green dots represent transplanted motoneurons. Nt, Notochord. 
A

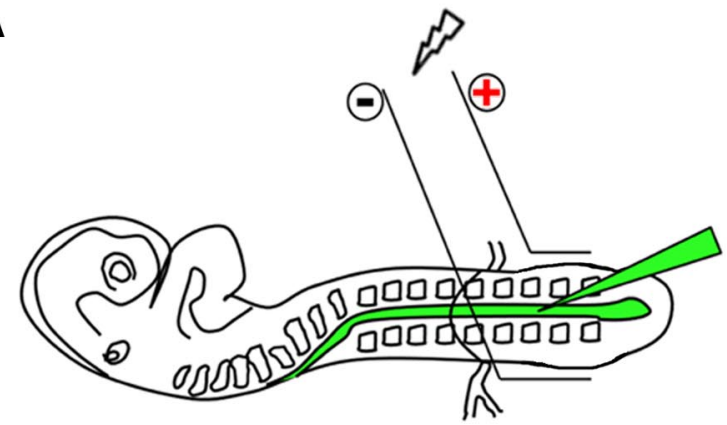

B

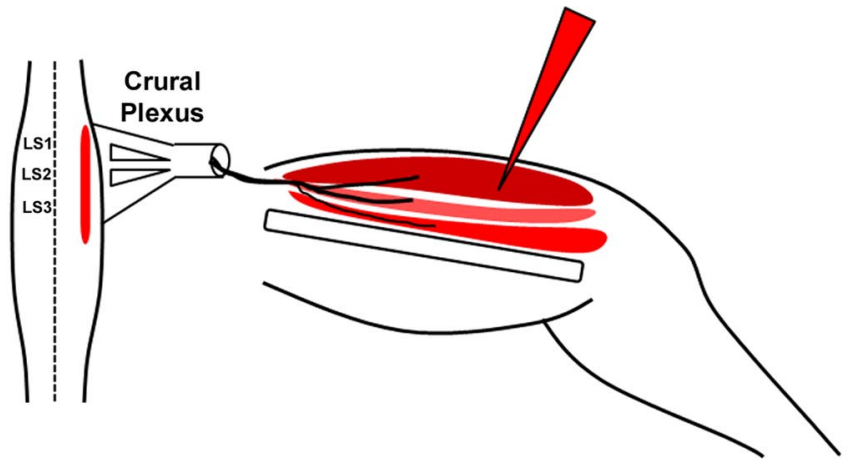

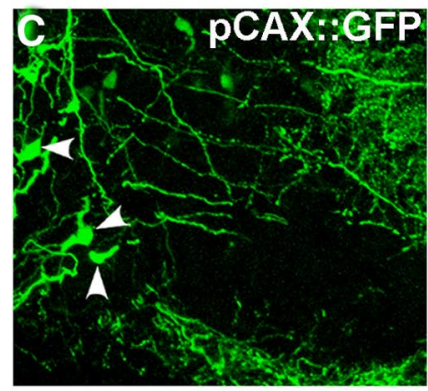
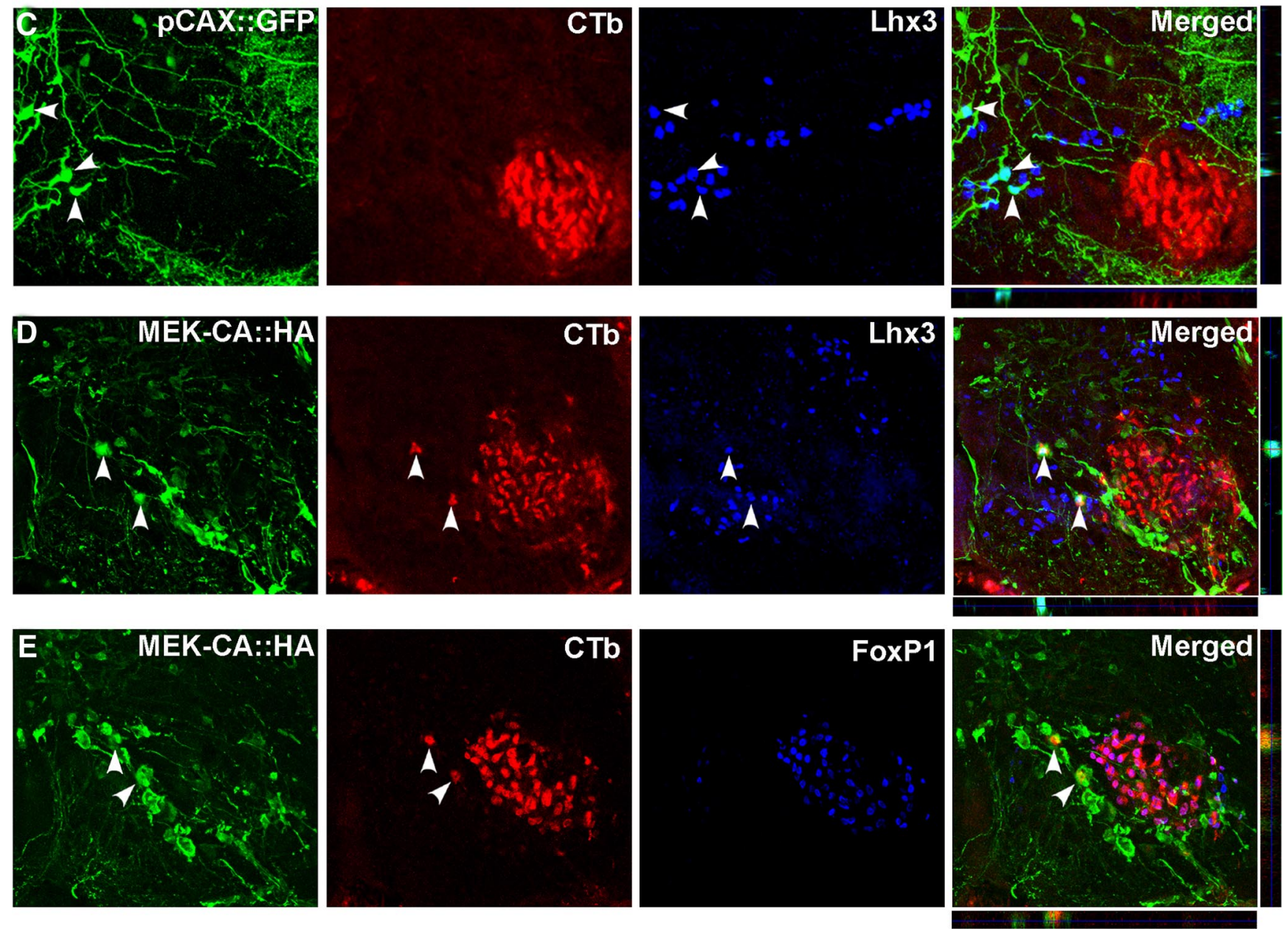

Figure 7. Constitutively activating MEK in MMCm motoneurons leads to axonal misprojections. $A, B$, Schematic representation showing the location of electrodes used in electroporations $(\boldsymbol{A})$ and muscle group injected with Alexa Fluor 594-conjugated (Tb (B). C, Immunolabeling and confocal imaging revealed that none of the pCAX::GFP-transfected neurons (green panel; arrowheads) expressing Lhx3 (blue panel; arrowhead) contained CTb (Alexa Fluor 594-conjugated cholera toxin B used to back-label neurons) (red panel). Individual sections in both the $x-Z$ (horizontal strip, below merged image) and $y-z$ (vertical strip, beside merged panel) orthogonal planes confirmed colocalization of GFP and Lhx3 (arrowheads in merged panel). $D$, Immunolabeling and confocal imaging showed several HA-immunopositive (green panel) and Lhx3-immunopositive (blue panel) cells containing (Tb (red panel; arrowheads). Imaging in both the $x-z$ and $y-z$ orthogonal planes confirmed colocalization of the three stains. $\boldsymbol{E}$, Confocal imaging showed that none of the HA ${ }^{+}$cells (green panel; arrowhead) containing CTb (red panel; arrowhead) coexpressed the LMC marker FoxP1 (blue panel and merged).

to show that selective targeting of MMCm motor axons is mediated through the MAPK/ERK signaling pathway, downstream of FGFR1 activation by FGF8.

Extracellular signaling pathways regulating motor axon guidance

Motor axons grow to their appropriate muscle targets during development by making a series of binary decisions at discrete choice points along their trajectory (Dickson, 2002; Kramer et al.,
2006). The first binary choice point occurs at the base of the DRG, where MMCm motor axons branch dorsally away from ventralprojecting LMC motor axons (Landmesser, 1980). Several lines of evidence indicate that this directional growth is attributable to a chemoattractive response mediated through FGF8/FGFR1 signaling. First, mRNA for FGF8 is expressed in the myotome (Crossley and Martin, 1995; Stolte et al., 2002). Second, MMCm motoneurons express FGFR1 when their axons reach the base of the DRG (Stolte et al., 2002; Shirasaki et al., 2006). Third, cul- 
tured spinal cord explants enriched in MMCm motoneurons grow neurites toward epaxial muscle primordial tissue and FGF8-loaded beads; growth in both cases is significantly attenuated when FGFR signaling is inhibited (Shirasaki et al., 2006). Finally, some motoneurons in FGFR $1^{f l f l}$;Nestin::Cre mice misproject at the level of the DRG (Shirasaki et al., 2006).

Our data support the hypothesis that FGF8 is a chemoattractant for FGFR1 ${ }^{+}$MMCm motoneurons (Shirasaki et al., 2006). In addition, our results indicate that ES cell-derived MMCm motoneurons use the same axon guidance mechanisms as their endogenous counterparts. Specifically, we found that ES cellderived motoneurons preferentially grew axons toward FGF8 in vitro but only if they expressed FGFR1 (Figs. 1,2). Furthermore, unlike motoneurons derived from wild-type ES cells (Soundararajan et al., 2006, 2007), ES cell-derived motoneurons lacking FGFR1 misprojected axons into the limb when transplanted into the neural tube of developing chick embryos (Fig. 3). Interestingly, axonal misprojections were greater in the present study compared with those reported in the FGFR $1^{\text {fl/fl }}$;Nestin::Cre mice (Shirasaki et al., 2006). The more severe phenotype in our study could be attributable to species differences or properties intrinsic to ES cell/chick chimeras. Alternatively, it could reflect differences in the timing of FGFR1 deletion from developing motoneurons. Because FGFR1 ${ }^{-1-}$ mice do not develop beyond grastrulation (Yamaguchi et al., 1994; Shirasaki et al., 2006), Shirasaki et al. (2006) used a Cre/Lox approach to delete FGFR1 from neuronal cells using a Nestin::Cre transgenic mouse. However, because both FGFR1 alleles were floxed, the possibility remained that excision of FGFR1 was incomplete (Shirasaki et al., 2006). Furthermore, Cre recombinase is not activated in Nestin::Cre mice until E11 (Tronche et al., 1999), a time when most motor axons have already reached the base of the DRG (Luria and Laufer, 2007). Consequently, MMCm motor axons expressing FGFR1 at the time they reached the first decision choice point in the FGFR1 $1^{f l f l}$;Nestin::Cre mice would most likely project correctly to the dermomyotome. In our system, transplanted $F G F R 1^{-1-}$ ES cell-derived motoneurons never expressed FGFR1. Consequently, their projection patterns may better reflect how MMCm motoneurons would grow if they lacked FGFR1 signaling from the onset of axogenesis.

FGF8-mediated chemoattraction is not limited to MMCm motoneurons. Trochlear motor axons grow, at least in part, toward the isthmic region of the developing hindbrain in response to FGF8 (Irving et al., 2002). Like trochlear motoneurons (Colamarino and Tessier-Lavigne, 1995), MMCm motor axons use multiple cooperative guidance signals to navigate to their correct target. MMCm motor axons selectively extend through the rostral half-sclerotome via attractive adhesion that appears to be mediated through EphA4/ephrinA5 signaling (Eberhart et al., 2004). This attraction, along with other unidentified guidance cues, probably explains why some transplanted ES cell-derived MMCm motoneurons correctly projected to epaxial muscles in the absence of FGFR1 signaling (Fig. 3). The greater prevalence of wandering axons in chick embryos receiving ES cell-derived motoneurons pretreated with SU5402 (supplemental Fig. 5, available at www.jneurosci.org as supplemental material) compared with those transplanted with FGFR1 $1^{-/-}$motoneurons suggests that additional FGFRs (e.g., FGFR3) (Philippe et al., 1998) may be involved in axon navigation at this choice point. Indeed, several FGFs are expressed by the dermomyotome at the time of MMCm axonal targeting, including FGF2, FGF4, and FGF9 (Niswander and Martin, 1992; Crossley and Martin, 1995; Colvin et al., 1996; Thisse and Thisse, 2005). The precise role these additional FGFs play in MMCm motor axon targeting remains to be determined.

\section{Intracellular signaling pathways regulating axonal growth}

Extracellular guidance cues mediate axonal growth by activating distinct intracellular signaling pathways, triggering the reorganization and assembly of cytoskeletal proteins within the growth cone (Markus et al., 2002a; Huber et al., 2003). In this study, we chose to examine two intracellular signaling pathways known to regulate axonal growth and guidance of neurons downstream of receptor activation (Zhou and Snider, 2006). Our results indicate that FGF8-induced outgrowth from MMCm motoneurons in vitro (Fig. 5) and directional growth of MMCm motor axons toward the dermomyotome in ovo (Figs. 6,7 ) require activation of the MAPK/ERK pathway downstream of FGFR1. This pathway has been implicated previously in neurite extension stimulated by neurotrophic factors activating Trk receptors (Atwal et al., 2000), netrin-1 (Tang and Kalil, 2005), Semaphorin 7A (Pasterkamp et al., 2003), FGF2 (Webber et al., 2005), and by cell adhesion molecules such as N-cadherin, laminin, and L1 (Schmid et al., 2000). In addition to promoting outgrowth, MAPK/ERK signaling is also required to reorient cultured Xenopus spinal neurons toward the chemoattractant Netrin-1 (Forcet et al., 2002).

Although additional MAPK/ERK-independent pathways undoubtedly regulate $\mathrm{MMCm}$ motor axon targeting, it appears that $\mathrm{PI} 3 \mathrm{~K} / \mathrm{Akt}$ is not involved, at least for FGF8-induced neurite outgrowth in vitro (Fig. 5). These results are somewhat surprising because the PI3K/Akt pathway is involved in neurite extension stimulated by neurotrophic factors activating Trk receptors in superior sympathetic ganglia and rat sensory neurons (Atwal et al., 2000; Markus et al., 2002b). Additionally, Xenopus spinal neurons, injected with rat TrkA mRNA, turn toward gradients of NGF in culture (Ming et al., 1999). It is not entirely clear why different neuronal populations use separate signaling pathways to regulate growth toward a chemoattractant. However, because PI3K/Akt is a critical mediator of growth factor-induced neuronal survival (Markus et al., 2002a), it is possible that involvement of this pathway in directional growth is more likely to occur when the guidance cue also acts as a neurotrophin in the same cell.

How does activation of the MAPK/ERK pathway regulate MMCm motor axon guidance? Some effects probably result from phosphorylation of cytoskeletal elements such as microtubuleassociated proteins and neurofilaments by ERK (Ray and Sturgill, 1987). This notion is supported by studies showing that MAPK/ ERK is asymmetrically activated across the growth cone of Xenopus spinal neurons while turning toward a gradient of BDNF (Guirland et al., 2004). MAPK/ERK also regulates local protein translation in isolated retinal growth cones when exposed to axon guidance molecules (Campbell and Holt, 2003). Because retinal growth cones fail to turn toward chemoattractants when local protein synthesis is inhibited (Campbell and Holt, 2003), MAPK/ ERK may mediate directional growth by maintaining the appropriate concentration of guidance-related proteins at the leading edge of the growth cone (Zhou and Snider, 2006). Future experiments using this novel ES cell/chick chimera model system will likely help resolve these important, unanswered issues.

\section{Model systems using ES cell-derived neurons}

This study underscores the effectiveness of using ES cell-derived neurons as a tool to investigate intracellular mechanisms regulating complex behaviors such as axon guidance. Because genetically modified ES cells are readily obtainable, the functions of 
numerous proteins can be screened over a relatively short period of time. The ES cell model system is augmented further when combined with chick embryo transplantation studies, allowing rapid examination of protein function in a complex in vivo environment. Although this type of analysis can be conducted using temporal and spatial conditional knock-out mice, ES cell/chick chimeras circumvent many problems associated with transgenic mice, including cost, embryonic lethality, unpredictable genetic penetrance, delayed onset of Cre-recombinase activity, and misleading phenotypes attributable to protein compensation. The ES cell/chick chimera model system will undoubtedly gain broader appeal as technology to differentiate stem cells into a wider range of specific neuronal subtypes is further refined. Finally, this model system may prove useful for understanding motoneuron disorders such as amyotrophic lateral sclerosis in which complex cell-cell interactions likely underlie the pathophysiology of the disease.

\section{References}

Atwal JK, Massie B, Miller FD, Kaplan DR (2000) The TrkB-Shc site signals neuronal survival and local axon growth via MEK and P13-kinase. Neuron 27:265-277.

Barres BA, Silverstein BE, Corey DP, Chun LL (1988) Immunological, morphological, and electrophysiological variation among retinal ganglion cells purified by panning. Neuron 1:791-803.

Campbell DS, Holt CE (2003) Apoptotic pathway and MAPKs differentially regulate chemotropic responses of retinal growth cones. Neuron 37:939-952.

Colamarino SA, Tessier-Lavigne M (1995) The axonal chemoattractant netrin-1 is also a chemorepellent for trochlear motor axons. Cell 81:621-629.

Colvin JS, Bohne BA, Harding GW, McEwen DG, Ornitz DM (1996) Skeletal overgrowth and deafness in mice lacking fibroblast growth factor receptor 3. Nat Genet 12:390-397.

Cooper MK, Porter JA, Young KE, Beachy PA (1998) Teratogen-mediated inhibition of target tissue response to Shh signaling. Science 280:16031607.

Crossley PH, Martin GR (1995) The mouse Fgf8 gene encodes a family of polypeptides and is expressed in regions that direct outgrowth and patterning in the developing embryo. Development 121:439-451.

Dickson BJ (2002) Molecular mechanisms of axon guidance. Science 298:1959-1964.

Dudek H, Datta SR, Franke TF, Birnbaum MJ, Yao R, Cooper GM, Segal RA, Kaplan DR, Greenberg ME (1997) Regulation of neuronal survival by the serine-threonine protein kinase Akt. Science 275:661-665.

Eberhart J, Swartz ME, Koblar SA, Pasquale EB, Krull CE (2002) EphA4 constitutes a population-specific guidance cue for motor neurons. Dev Biol 247:89-101.

Eberhart J, Barr J, O'Connell S, Flagg A, Swartz ME, Cramer KS, Tosney KW, Pasquale EB, Krull CE (2004) Ephrin-A5 exerts positive or inhibitory effects on distinct subsets of EphA4-positive motor neurons. J Neurosci 24:1070-1078.

Forcet C, Stein E, Pays L, Corset V, Llambi F, Tessier-Lavigne M, Mehlen P (2002) Netrin-1-mediated axon outgrowth requires deleted in colorectal cancer-dependent MAPK activation. Nature 417:443-447.

Gallo G, Letourneau PC (1998) Localized sources of neurotrophins initiate axon collateral sprouting. J Neurosci 18:5403-5414.

Glebova NO, Ginty DD (2005) Growth and survival signals controlling sympathetic nervous system development. Annu Rev Neurosci 28:191-222.

Guirland C, Suzuki S, Kojima M, Lu B, Zheng JQ (2004) Lipid rafts mediate chemotropic guidance of nerve growth cones. Neuron 42:51-62.

Hamburger V, Hamilton HL (1951) A series of normal stages in the development of the chick embryo. J Morphol 88:49-82.

Hanson MG, Landmesser LT (2004) Normal patterns of spontaneous activity are required for correct motor axon guidance and the expression of specific guidance molecules. Neuron 43:687-701.

Helmbacher F, Schneider-Maunoury S, Topilko P, Tiret L, Charnay P (2000) Targeting of the EphA4 tyrosine kinase receptor affects dorsal/ventral pathfinding of limb motor axons. Development 127:3313-3324.

Hollyday M, Hamburger V (1977) An autoradiographic study of the formation of the lateral motor column in the chick embryo. Brain Res 132:197-208.

Huber AB, Kolodkin AL, Ginty DD, Cloutier JF (2003) Signaling at the growth cone: ligand-receptor complexes and the control of axon growth and guidance. Annu Rev Neurosci 26:509-563.

Irving C, Malhas A, Guthrie S, Mason I (2002) Establishing the trochlear motor axon trajectory: role of the isthmic organiser and Fgf8. Development 129:5389-5398.

Kablar B, Rudnicki MA (1999) Development in the absence of skeletal muscle results in the sequential ablation of motor neurons from the spinal cord to the brain. Dev Biol 208:93-109.

Kania A, Jessell TM (2003) Topographic motor projections in the limb imposed by LIM homeodomain protein regulation of ephrin-A:EphA interactions. Neuron 38:581-596.

Kennedy TE, Serafini T, de la Torre JR, Tessier-Lavigne M (1994) Netrins are diffusible chemotropic factors for commissural axons in the embryonic spinal cord. Cell 78:425-435.

Kramer ER, Knott L, Su F, Dessaud E, Krull CE, Helmbacher F, Klein R (2006) Cooperation between GDNF/Ret and ephrinA/EphA4 signals for motor-axon pathway selection in the limb. Neuron 50:35-47.

Landmesser L (1978) The distribution of motoneurones supplying chick hind limb muscles. J Physiol 284:371-389.

Landmesser LT (1980) The generation of neuromuscular specificity. Annu Rev Neurosci 3:279-302.

Landmesser LT (2001) The acquisition of motoneuron subtype identity and motor circuit formation. Int J Dev Neurosci 19:175-182.

Luria V, Laufer E (2007) Lateral motor column axons execute a ternary trajectory choice between limb and body tissues. Neural Dev 2:13.

Luria V, Krawchuk D, Jessell TM, Laufer E, Kania A (2008) Specification of motor axon trajectory by ephrin-B:EphB signaling: symmetrical control of axonal patterning in the developing limb. Neuron 60:1039-1053.

Markus A, Patel TD, Snider WD (2002a) Neurotrophic factors and axonal growth. Curr Opin Neurobiol 12:523-531.

Markus A, Zhong J, Snider WD (2002b) Raf and akt mediate distinct aspects of sensory axon growth. Neuron 35:65-76.

Mathieu M, Chatelain E, Ornitz D, Bresnick J, Mason I, Kiefer P, Dickson C (1995) Receptor binding and mitogenic properties of mouse fibroblast growth factor 3. Modulation of response by heparin. J Biol Chem 270:24197-24203.

Messersmith EK, Leonardo ED, Shatz CJ, Tessier-Lavigne M, Goodman CS, Kolodkin AL (1995) Semaphorin III can function as a selective chemorepellent to pattern sensory projections in the spinal cord. Neuron 14:949-959.

Miles GB, Yohn DC, Wichterle H, Jessell TM, Rafuse VF, Brownstone RM (2004) Functional properties of motoneurons derived from embryonic stem cells. J Neurosci 24:7848-7858.

Ming G, Song H, Berninger B, Inagaki N, Tessier-Lavigne M, Poo M (1999) Phospholipase C-gamma and phosphoinositide 3-kinase mediate cytoplasmic signaling in nerve growth cone guidance. Neuron 23:139-148.

Niswander L, Martin GR (1992) Fgf-4 expression during gastrulation, myogenesis, limb and tooth development in the mouse. Development 114:755-768.

Ohuchi H, Nakagawa T, Yamamoto A, Araga A, Ohata T, Ishimaru Y, Yoshioka H, Kuwana T, Nohno T, Yamasaki M, Itoh N, Noji S (1997) The mesenchymal factor, FGF10, initiates and maintains the outgrowth of the chick limb bud through interaction with FGF8, an apical ectodermal factor. Development 124:2235-2244.

Pasterkamp RJ, Peschon JJ, Spriggs MK, Kolodkin AL (2003) Semaphorin 7A promotes axon outgrowth through integrins and MAPKs. Nature 424:398-405.

Philippe JM, Garces A, deLapeyière O (1998) Fgf-R3 is expressed in a subset of chicken spinal motorneurons. Mech Dev 78:119-123.

Ray LB, Sturgill TW (1987) Rapid stimulation by insulin of a serine/threonine kinase in 3T3-L1 adipocytes that phosphorylates microtubuleassociated protein 2 in vitro. Proc Natl Acad Sci U S A 84:1502-1506.

Schmid RS, Pruitt WM, Maness PF (2000) A MAP kinase-signaling pathway mediates neurite outgrowth on L1 and requires Src-dependent endocytosis. J Neurosci 20:4177-4188.

Shirasaki R, Pfaff SL (2002) Transcriptional codes and the control of neuronal identity. Annu Rev Neurosci 25:251-281.

Shirasaki R, Lewcock JW, Lettieri K, Pfaff SL (2006) FGF as a target-derived chemoattractant for developing motor axons genetically programmed by the LIM code. Neuron 50:841-853.

Soundararajan P, Miles GB, Rubin LL, Brownstone RM, Rafuse VF (2006) Motoneurons derived from embryonic stem cells express transcription factors and develop phenotypes characteristic of medial motor column neurons. J Neurosci 26:3256-3268. 
Soundararajan P, Lindsey BW, Leopold C, Rafuse VF (2007) Easy and rapid differentiation of embryonic stem cells into functional motoneurons using sonic hedgehog-producing cells. Stem Cells 25:1697-1706.

Stolte D, Huang R, Christ B (2002) Spatial and temporal pattern of Fgf- 8 expression during chicken development. Anat Embryol (Berl) 205:1-6.

Tang F, Kalil K (2005) Netrin-1 induces axon branching in developing cortical neurons by frequency-dependent calcium signaling pathways. J Neurosci 25:6702-6715.

Thisse B, Thisse C (2005) Functions and regulations of fibroblast growth factor signaling during embryonic development. Dev Biol 287:390-402.

Tronche F, Kellendonk C, Kretz O, Gass P, Anlag K, Orban PC, Bock R, Klein R, Schütz G (1999) Disruption of the glucocorticoid receptor gene in the nervous system results in reduced anxiety. Nat Genet 23:99-103.
Tsuchida T, Ensini M, Morton SB, Baldassare M, Edlund T, Jessell TM, Pfaff SL (1994) Topographic organization of embryonic motor neurons defined by expression of LIM homeobox genes. Cell 79:957-970.

Webber CA, Chen YY, Hehr CL, Johnston J, McFarlane S (2005) Multiple signaling pathways regulate FGF-2-induced retinal ganglion cell neurite extension and growth cone guidance. Mol Cell Neurosci 30:37-47.

Wichterle H, Lieberam I, Porter JA, Jessell TM (2002) Directed differentiation of embryonic stem cells into motor neurons. Cell 110:385-397.

Yamaguchi TP, Harpal K, Henkemeyer M, Rossant J (1994) fgfr-1 is required for embryonic growth and mesodermal patterning during mouse gastrulation. Genes Dev 8:3032-3044.

Zhou FQ, Snider WD (2006) Intracellular control of developmental and regenerative axon growth. Philos Trans R Soc Lond B Biol Sci 361:1575-1592. 